\section{Pragmatism is not enough}

SIR-It is a well-publicized fact that many species of organisms are in danger of extinction from human activities, especially in the humid tropics where massive deforestation threatens to exterminate countless forms not yet discovered by science. Fortunately, many individuals and organizations have risen to oppose the shortsighted economic and social behaviour that causes this problem - above all, the continued growth of human populations. Many arguments have been adduced for the importance of species preservation, including the actual or potential value of species as food or genetic resources, agents of biological control, components of healthy ecosystems and of our own life-support systems, or objects of aesthetic or intellectual interest. E. O. Wilson, in his recent book Biophilia, offers a more subtle argument: the innate affinity of man with other living things, and the fundamental connection between the value we place on them and the value we place on ourselves.

All these arguments are valid, and worth making at every opportunity. However, I suggest that we make a serious and possibly fatal tactical error when we rely solely on such justifications for species preservation. They are all based on the same flawed assumption: that the survival of a species is ultimately justified by its usefulness to man.

Take, for example, the popular argument that the humid tropics are vast untapped reservoirs of potentially valuable genetic diversity. This is true, and among the better reasons for preserving the rainforests. But what will happen to this justification if advances in genetic engineering in the next century make wild gene pools superfluous (or seemingly superfluous) for practical applications? The universal tendency of our technology, after all, is to replace natural products with synthetic ones, and to reduce our dependence on wild species of every sort.

When scientists try to oppose polluters, exploiters and developers solely with these kinds of pragmatic arguments about the value of species, ecosystems or gene pools to human well-being, we have already been manoeuvred into fighting on the ground they have chosen. Our pragmatic arguments for the long-term value of species will be weighed against their pragmatic arguments for the immediate needs of human beings. If an impartial judge rules that their arguments are more compelling and that a floodcontrol dam will objectively provide more tangible benefits to humanity than will an endangered species, to whom will scientists appeal?

If man's momentary need is allowed to decide the fate of other species, then in the long run the odds are stacked against them. Yet as scientists we owe our allegiance to objectivity and therefore to pragmatism. This, in my view, is why we cannot afford to speak only as scientists, or to let ourselves be limited by that label. We are scientists second and human beings first, and therefore must judge and act and justify our actions according to criteria that transcend science and pragmatism; namely, moral criteria.

If we are ultimately to preserve our biological inheritance, the only position we can take that is sufficiently strong the only ground that is sufficiently high to be defended against the pragmatists, the economists, the politicians and the exploiters - is that we humans, as the de facto stewards of nature, are morally accountable for our stewardship. At the very least, we are accountable to posterity, and for such blunders as we have already committed with toxic and radioactive wastes, we may even live to be cursed by our own children. Those who acknowledge an authority above and beyond this world have still more reason to fear judgement. But if we pride ourselves on any claim to morality at all, whatever, its philosophical basis, that morality must lead is to use nature in a way that will preserve its diversity permanently intact.

This, admittedly, is a moral principle that is more implicit than explicit in many of the theologies and philosophies of the past. But just as there is progress in scientific understanding, there is also progress in moral philosophy and in what we are pleased to call "civilization". Little by little, the human race has grudgingly come to admit that certain things are simply wrong - such as murder, theft, slavery, torture, racism, genocide and even cruelty to animals. Though still committed, these are generally acknowledged, at least, to be crimes. Extermination of a species is also a crime. It is murder of a unique and irreplaceable evolutionary "individual"; it is theft at the expense of our own posterity; and it is a form of genocide as indefensible as any other.

These are the facts we must force mankind to admit, and ultimately to codify in enforceable international law; and there is no time to waste.

DARYL P. DOMNING

Department of Anatomy,

Howard University,

Washington, DC 20059, USA

\section{Bees in SE Asia}

SIR-As people of, we believe, "some importance", we read with dismay your editorial on "Bees in South-East Asia" (Nature 317, 190; 1985). Scientific thinking on this issue is clouded by political rhetoric on both sides. We wish to protest about a different matter - your judgement that "nobody of much importance seems to have taken the biological warfare scare seriously".

We take it seriously, as do some of our patients - the H'Mong people of Laos. It is our privilege to work at a hospital which cares for these surviving refugees. They know, perhaps better than any of us, just how seriously to take it.

Atrocities are indeed hard to imagine. To suggest that these people, who believe that biological warfare has been used against them, are "nobody of much importance", rings of past atrocities which also were denied.

We call on you to be more circumspect in conferring the mantle of importance on some people and not on others. And we caution that science is not well served by the assumption that the "important" people are more likely to be astute observers or logical thinkers.

KAREN R. REEVES St Elizabeth's Hospital, William H. ANDERSON 736 Cambridge Street, Boston, Massachusetts 02135, USA

\section{Leprosy vaccine}

SIR-Your report (Nature 317, 665; 1985) about the proposed test of the World Health Organization (WHO) leprosy vaccine in India does not accurately represent the status of the method used to prepare the vaccine. Although this has not been formally published, the protocol is freely available from WHO and elsewhere and involves no proprietary or patented processes. Further, I have demonstrated the process in two separate laboratories in India, both of which have all the necessary apparatus and chemicals. Several visitors from India have also been shown how to purify $M$. leprae by the process. So it is not clear what technology needs to be transferred. The involvement of the company Wellcome in the matter is simply because materials for use in man must be prepared in licensed permises; there is no question of either development or exploitation of the process by Wellcome.

Your correspondent correctly comments that the main problem of indigenous production of the WHO-type vaccine is that the armadillo colony set up by the Indian Council for Medical Research failed to thrive. These are difficult animals to keep, but there is no restriction on advice and training on how to keep them.

There may indeed be instances where "multinationals" have restricted access to products by developing countries, but the leprosy vaccine is not such an instance.

Philip Draper

National Institute

for Medical Research,

Mill Hill, London NW7 1AA, UK 